\title{
PENERAPAN DAN PERKEMBANGAN REKSADANA SYARIAH DI INDONESIA
}

\author{
Leo Firmansyah \\ Pascasarjana UIN Sunan Gunung Djati Bandung \\ leofirmansyah037@gmail.com
}

\begin{abstract}
ABSTRAK
Tulisan ini dilatarbelakangi oleh beberapa penelitian mengenai perkembangan dan penerapan reksadana syariah di Indonesia, serta melihat kondisi yang terjadi di dunia pasar modal Indonesia yang saat ini sedang menjadi tren di kalangan ekonom muda. Tulisan ini memiliki tujuan untuk memberikan wawasan lebih dalam, mengenai penerapan dan perkembangan reksadana syariah yang telah terjadi di Indonesia di lihat dari berbagai sumber penelitian dan literatur yang ada. Penulis memakai metode penulisan studi literatur dengan menelaah beberapa jurnal dan litertur yang terkait dengan perkembangan dan penerapan reksadana syariah yang telah selama ini terjadi di Indonesia. Hasil telaah tesebut nantinya akan digunakan untuk menberikan dan memperjelas wawasan mengenai penerapan dan perkembangan reksadana syariah di Indonesia.
\end{abstract}

Kata Kunci: Reksadana Syariah, Penerapan, Perkembangan, Studi Literatur. 


\section{PENDAHULUAN}

Tulisan ini dilatarbelakangi oleh penelitian Winda Wardiah dan Elis Mediawati (2016) mengenai kinerja reksadana syariah di Indonesia, penelitian ini menunjukkan bahwa reksadana cipta syariah equity merupakan reksadana saham syariah yang memiliki kinerja terbaik dibandingkan dengan reksadana saham syariah lainnya yang ada di Indonesia. ${ }^{1}$ Selain penelitian tersebut Amal Hamzah dan Agustinus Yohanes (2014) juga melakukan perbandingan pada evaluasi kinerja reksadana syariah dengan reksadana konvensional, pada penelitian ini menunjukkan secara umum tidak ditemukan perbedaan signifikan antara reksadana jenis saham syariah dengan reksadana jeis saham konvensional. ${ }^{2}$

Selain dua penelitian di atas $\mathrm{M}$. Rasyid Ridha, Bismar Nasution dan Mahmul Siregar (2013) membuat penelitian mengenai peranan reksadana syariah dalam meningkatkan investasi di Indonesia, hasil penelitian ini menunjukkan bahwa reksadana syariah sama-sama di atur oleh pemerintah Indonesia melalui undang-undang dan fatwa DSN MUI, bentuk-bentuk pelaksanaan akad dalam mekanisme investasi reksadana miri dengan investasi bagi hasil, dan reksadana syariah di lindungi oleh beberapa hukum yang di atur pemerintah Indonesia guna

\footnotetext{
${ }^{1}$ Waridah, W., \& Mediawati, E. (2016). Analisis Kinerja Reksadana Syariah. Jurnal Riset Akuntansi Dan Keuangan, 4(2). https://doi.org/10.17509/jrak.v4i2.$\underline{4043}$

2 Hamzah, A., \& Yohanes, A. (2014). Analisis Perbandingan Kinerja Reksadana Syariah dengan Reksadana Konvensional Jenis Saham. Jurnal MIX Vol.IV No.3. HIm. 396.
}

melindungi pelaksana reksadana syariah di indonesia. ${ }^{3}$

Keberadaan Reksadana di Indonesia dapat dikatakan telah dimulai pada saat diaktifkannya kembali pasar modal di Indonesia. Pada saat itu penerbitan Reksadana dilakukan oleh persero (BUMN) yang didirikan khusus untuk menunjang kegiatan pasar modal Indonesia, sekalipun pada saat itu belum ada pengaturan khusus mengenai Reksadana. Istilah Reksadana lebih dikenal pada tahun 1990 dengan diizinkannya pelaku pasar modal untuk menerbitkan Reksadana melalui Keppres No. 53 Tahun 1990 tentang Pasar Modal.

Berdasarkan peraturan tersebut maka reksadana wajib didaftarkan pada Securities and Exchange Commission atau biasa disebut SEC yaitu sebuah komisi di Amerika yang menangani perdagangan surat berharga dan pasar modal. Selain itu pula, penerbit reksadana wajib untuk menyediakan prospektus yang memuat informasi guna keterbukaan informasi reksadana, juga termasuk surat berharga yang menjadi objek kelolaan, informasi mengenai manajer investasi yang menerbitkan reksadana. Melihat dari beberapa penelitian yang telah dilakukan dan beberapa kenyataan yang terjadi pada reksadana syariah di Indonesia, penulis dapat menegaskan mengenai pentingnya mengenai reksadana syariah. Atas dasar beberapa hal yang sudah diuraikan di

${ }^{3}$ Ridha, M.R., Nasution, B., \& Siregar, M. (2013). Peranan Reksadana Syariah dalam Peningkatan Investasi di Indonesia. Jurnal Hukum Ekonomi Vol 02. No.02 HIm. 1. 
atas maka penulis memutuskan untuk membuat tulisan mengenai reksadana syariah.

\section{Kajian Teori}

Di Indonesia reksadana telah ada sejak tahun 1977 melalui PT. Danareksa. Produk yang ditawarkan masih belum bervariasi seperti sekarang, dan penyebarannya masih terbatas pada kalangan tertentu. Pada tahun 1997, perusahaan sekuritas milik Negara PT. Danareksa menjadi pionir dalam menerbitkan reksadana syariah. Reksadana menjadi instrument pasar modal pertama yang beroprasi sesuai syariah Islam dan sbagai langkah awal lahirnya pasar modal syariah.

\section{Pengertian Reksadana Syariah}

Reksadana Syariah berasal dari kata "reksa", yang berarti kelola atau pelihara. "Dana" berarti uang, dan "Syariah" adalah atauran-aturan yang sesuai dengan Islam. ${ }^{4}$ Reksadana di Inggris dikenal dengan sebutan unit trust yang berarti unit (saham) kepercayaan dan di Amerika dikenal dengan sebutan mutual fund yang berarti dana bersama dan di Jepang dikenal dengan sebutan investment fund yang berarti pengeolaan dana untuk investasi berdasarkan kepercayaan. ${ }^{5}$

Menurut Fatwa Dewan Syariah Nasional (DSN) Nomor 20/DSNMUI/IX/2000, reksadana syariah adalah

\footnotetext{
4 Ahmad Rodoni, Lembaga Keuangan, (Jakarta Timur: Zikrul Hakim, 2008), h.151

5 Jaka E. Cahyono, Cara Jitu Memilih Untung dari Reksadana, (Jakarta: Elex Media Komputindo, 2000), h. 16

reksadana yang beroperasi menurut ketentuan dan prinsip syariah Islam, baik dalam bentuk akad antara pemodal sebagai pemilik harta (Sahib al-mal/ rabb almal) dengan manajer investasi sebagai wakil sahib al-mal, maupun antara manajer investasi sebagai wakil dengan pengguna investasi. Dengan kata lain reksadana syariah dapat dirumuskan sebagai reksadana yang cara pengelolannya dan kebijakan investasinya mengacu pada syarit Islam. Misalnya reksadana syariah tidak berinvestasik pada saham-saham atau obligasi dari perusahaan yang pengelolaan atau produknya bertentangan dengan syariat Islam, misalnya: pabrik minuman keras, industri pertenakan babi, jasa keuangan yang melibatkan riba dalam operasionalnya dan bisnis yang mengandung maksiat.

\section{Manfaat Reksadana Syariah}

Manfaat Reksadana Syariah adalah pertama, manfaat reksadana syariah bagi pemerintah dan bursa efek yaitu memobilisasi dana masyarakat, dimana reksadana (sebagai emiten) merupakan lahan yang tepat bagi investasi pemodal segala strata; baik besar maupun kecil. Investorinvestor lembaga akan lebih percaya kepada manajer investasi yang mengelola reksadana, meningkatkan peranan swasta nasional dalam menghimpun dana masyarakat, mendorong perdagangan suratsurat berharga dipasar modal Indonesia, sehingga dapat meningkatkan likuiditas bursa dan kapitalis pasar dan dapat 
mengoreksi tingkat bunga, karena pergeseran dana dari bank ke capital market. ${ }^{6}$

Kedua, manfaat reksadana syariah bagi investor yaitu hasil yang lebih optimal. Dengan dana yang relatif kecil, keuntungan investasi pada reksadana relatif tinggi daripada investasi pada produk perbankan. Selanjutnya, dana kita dikelola oleh manajer investasi yang memang memiliki kompetensi untuk melakukan investasi. Diversifikasi dengan dana yang lebih besar, investasi kita bisa tersebar dengan baik sehingga risikonya menjadi relatif lebih kecil. Bukan hanya itu, likuiditas terjamin dan harga fleksibel.

\section{Dasar Hukum Reksadana Syariah}

Pada prinsipnya setiap sesuatu dalam muamalat adalah dibolehkan selama tidak bertentangan dengan syariah, mengikuti kaidah fiqh yang dipegang oleh mazhab Hambali dan para fuqaha lainnya yaitu:

"Prinsip dasar dalam transaksi dan syarat-sayarat yang berkenaan dengannya ialah boleh diadakan, selama tidak dilarang oleh syariah atau bertentangan dengan nash syariah". (Al Fiqh Al Islamy wa Adillatuh, Juz IV hal. 199).

Allah SWT Memerintahkan orangorang yang beriman agar memenuhi akad yang mereka lakukan seperti disebut dalam Al-Qur'an:

"Hai Orang-orang yang beriman, penuhilah akad-akad itu." (QS. AlMaidah :1)

${ }^{6}$ Jaka E. Cahyono, Cara Jitu Memilih Untung dari Reksadana, (Jakarta: Elex Media Komputindo, 2000), h. 171-172.
Syarat-syarat yang berlaku dalam sebuah akad, adalah syarat-syarat yang ditentukan sendiri oleh kaum muslimin, selama tidak melanggar ajaran Islam. Rasulullah SAW memberi batasan tersebut dalam hadist:

"Perjanjian itu boleh bagi orang Islam kecuali perjanjian yang mengharamkan yang halal atau menghalalkan vang haram. Dan orang Islam itu wajib memenuhi syarat-syarat yang mereka kemukakan kecuali s'yarat yang mengharamkan yang haIal dan menghalalkan yang haram." (HR. Abu Dawud, Ibnu Majah dan Turmudzi dari Amr bin Auf).

Setiap jenis investasi tentu memuat perjanjian-perjanjian tertentu yang harus dipatuhi oleh para pelakunya. Menurut hadits di atas, selama investasi tersebut tidak memuat perjanjian yang mengharamkan yang halal atau menghalalkan yang haram, maka syariah Islam membolehkannya. Selain dari itu pemerintah Indonesia mengeluarkan peraturan melalui Fatwa Dewan Syariah Nasional fatwa No.20/DSN-MUI/IV/2001 yang menyatakan bahwa reksadana menjadi salah satu jenis investasi yang dibolehkan dalam Islam, namun dalam bentuk reksadana syariah.

Dalam reksadana konvensional berisi akad muamalah yang dibolehkan dalam Islam, yaitu jual beli dan bagi hasil (Mudharabah/Musyarakah), dan di sana terdapat banyak maslahat, seperti memajukan perekonomian, saling memberi keuntungan di antara para pelakunya meminimalkan resiko dalam pasar modal dan sebagainya. Namun di dalamnya juga 
ada hal-hal bertentangan dengan syariah, baik dalam segi akad, operasi, investasi, transaksi dan pembagian keuntungannya.

Syariah dapat menerima usaha semacam reksadana sepanjang hal yang tidak bertentangan denga syariah. Dr. Wahbah Az-Zuhaily berkata:

“Dan setiap syarat yang tidak bertentangan denga dasar-dasar syariat dan dapat disamakan hukumnya (diqiyaskan) dengan syarat-syarat yang sah". (al-Fiqh al Islamy Wa Adillatuh, hal 200).

Prinsip dalam berakad juga harus mengikuti hukum yang telah digariskan oleh Allah SWT yang disebutkan dalam Al- Quran:

"Hai orang-orang yang beriman, janganlah kamu saling memakan harta sesamamu dengan jalan yang batil, kecuali dengan jalan perniagaan yang berlaku dengan suka sama suka di antara kamu." (QS. An-Nisaa' : 29).

\section{Bentuk-bentuk Reksadana Syariah}

Berdasarkan Undang-Undang Pasar Modal Nomor 8 Tahun 1995 pasal 18, ayat (1), bentuk hukum reksadana di Indonesia ada dua, yakni reksadana berbentuk perseroan terbatas (PT. Reksa Dana) dan reksadana berbentuk Kontrak Investasi Kolektif (KIK). ${ }^{7}$ Badan Hukum perseroan (PT) Reksadana berbentuk perseroan (PT. Reksa Dana) merupakan badan hukum tersendiri yang didirikan untuk melakukan kegiatan reksadana. Ciri-ciri rek-

7 Sari, R. P. (2018). Perbandingan Reksadana Syariah Dengan Reksadana Konvensional Dalam Dunia Perbankan. Al-Intaj: Jurnal Ekonomi Dan Perbankan Syariah, 4(1). ttps://doi.org/10.29300/aij.v4i1.1203 sadana PT adalah bentuk hukumnya ádalah Perseroan Terbatas (PT), sponsor wajib menyetor sekurang-kurangnya $1 \%$ dari modal dasar, pemodal adalah pemegang saham, manajer investasi bertindak sebagai pengelola kekayaan reksadana, bank kustodian bertindak sebagai tempat penyimpanan dan pengadministrasian kekayaan reksadana.

Reksadana berbentuk Kontrak Investasi Kolektif (KIK). Kontrak Investasi Kolektif adalah kontrak yang dibuat antara manajer investasi dan bank kustodian yang juga mengikat pemegang unit penyertaan sebagai investor. Melalui kontrak ini manajer investasi diberi wewenang untuk mengelola portofolio efek dan Bank Kustodian diberi wewenang untuk melaksanakan penitipan dan administrasi investasi. Bank kustodian adalah bank yang memberikan jasa penitipan efek dan harta lainnya, seperti: menerima deviden, bunga, hak-hak lain, menyelesaikan traksaksi efek, dan mewakili pemegang rekening yang menjadi nasabahnya.

Ciri-ciri dari reksadana kontrak investasi kolektif adalah bentuk hukumnya adalah kontrak investasi kolektif, pengelolaan reksadana dilakukan oleh manager investasi berdasarkan kontrak, penyimpanan kekayaan investasi kolektif dilaksanakan oleh bank kustodion berdasarkan kontrak, menjual unit penyertaan secara terusmenerus sepanjang ada investor yang membeli, unit penyertaan tidak dicatat di bursa, investor dapat menjual kembali (redemption) unit penyertaan yang dimilikinya kepada manager inves- 
tasi yang mengelola, hasil penjualan/pembayaran kembali unit penyertaan akan dibebankan kepada kekayaan reksadana dan harga jual/beli unit penyertaan didasarkan atas Nilai Aktiva Bersih (NAB) per unit dihitung oleh Bank kustodian secara harian.

Dalam hal reksadana KIK, manajer investasi menghimpun dana dari masyarakat pemodal. Berarti dana ini berasal dari ratusan ribu pemodal; baik pemodal individu maupun pemodal institusi. Dana ini dikumpulkan dengan cara menjual unit penyertaan. Masyarakat yang membeli unit penyertaan reksadana akan mendapat tanda bukti berupa surat konfirmasi dari bank kustodion.

\section{Metode Penulisan}

Tulisan ini menggunakan metode penelitian studi literatur dengan menelaah dan menganalisis beberapa jurnal dan buku yang berhubungan erat dengan bidang perkembangan, penerapan reksadana syariah, dan investasi di Indonesia. Hasil analisa dari berbagai literatur akan dijadikan sebagai acuan dan sumber belajar dalam menguraikan materi-materi mengenai perkembangan dan penerapan reksadana syariah di Indonesia, sehingga penulis dan pembaca dapat memahami dengan jelas mengenai perkembangan dan penerapan reksadana syariah di Indonesia.

\section{PEMBAHASAN}

\section{Perbedaan Reksadana Syariah dan Reksadana Konvensional}

Kegiatan berinvestasi salah satunya dengan reksadana yang ada saat ini masih banyak mengandung unsur-unsur yang tidak sesuai dengan syariah Islam. Reksadana onvensional masih dijumpai unsur-unsur yang dilarang dalam Islam dan tidak sesuai dengan syariat Islam, khususnya dalam ketidakjelasan mengenai jenis kegiatan dan transaksi usaha apa yang akan didanai dan dikeluarkan oleh reksadana tersebut. Reksadana konvensional menggunakan metode perhitungan keuntungan antara pihak investor dengan manejer investasi adalah sah dan sesuai dengan ketentuan hukum Islam, karena dilaksanakan berdasarkan metode bagi hasil berupa bagi untung (profit sharing) ataupun bagi pendapatan (reveneue sharing).

Namun yang masih menimbulkan keragu-raguan (gharar) adalah dalam hal penyalurannya kepada pengguna investasi digunakan untuk kegiatan usaha pengguna investasi yang bersifat halal maupun tidak halal, karena dalam syariah tidak menggunakan sistem yang tidak jelas (Ghofur, 2008). ${ }^{8}$ Ada beberapa hal yang membedakan antara reksadana konvensional dan reksadana syariah antara lain: 


\section{Kelembagaan}

Lembaga keputusan tertinggi di syariah dalam hal keabsahan produk adalah Dewan Pengawas syariah (DPS) yang beranggotakan beberapa alim ulama dan ahli ekonomi syariah yang direkomendasikan oleh Dewan Pengawas Syariah Nasional Majelis Ulama Indonesia (DSNMUI). Proses kinerja dan transaksinya akan terus diikuti perkembangannya agar tidak keluar dari jalur syariah yang menjadi prinsip investasinya.

\section{Hubungan Investor dengan perusahaan}

Sistem bagi hasil mengenai keuntungan dan kerugian hubungan investor dengan perusahaan yang dimaksudkan disini adalah adanya kesepakatan antara kedua belah pihak dengan sistem mudharabah. Secara teknis, al-mudharabah adalah akad kerjasama usaha antara dua pihak dimana pihak pertama menyediakan seluruh (100\%) modal, sedangkan pihak lainnya menjadi pengelola. Seandainya kerugian tersebut karena kecurangan atau kelalaian pengelola maka pengelola harus bertanggungjawab atas kerugian tersebut. Dalam hal ini transaksi jual beli, saham-saham dalam reksadana syariah dapat diperjualbelikan. Sahamsaham dalam reksadana syariah merupakan yang harta (mal) yang dibolehkan untuk diperjualbelikan dalam syariah, karena nilai saham tersebut jelas tidak adanya unsur penipuan (gharar) dalam transaksi.
Kegiatan Investasi Reksadana Syariah

Berinvestasi dengan reksadana syariah dapat melakukan apa saja sepanjang tidak bertentangan dengan prinsip syariah, yang ditentukan oleh Dewan Pengawas Syariah. Dalam kaitannya dengan saham-saham yang diperjual belikan dibursa saham, BEJ sudah mengeluarkan daftar perusahaan yang tercantum dalam bursa yang sesuai dengan syariah Islam atau saham-saham yang tercatat di Jakarta Islamic Index (JII). Bertransaksi dengan reksadana syariah tidak diperbolehkan melakukan tindakan spekulasi, yang didalamnya mengandung gharar seperti penawaran palsu dan tindakan spekulasi lainnya. ${ }^{9}$

\section{Proses Pengelolaan Reksadana Syariah}

Reksadana syariah dilandasi oleh prinsip syariah, karena itu proses pengelolaan reksadana syariah juga akan selalu dilandasi oleh prinsip-prinsip dan mekanisme yang sesuai dengan syariah Islam. Secara sederhana proses pengelolaan investasi reksadana syariah dapat digambarkan sebagai berikut:

9 Zakariya, M. (2017). Pertumbuhan Lembaga Reksadana Syariah Di Indonesia. JES (Jurnal Ekonomi Syariah), 1(2), 275-285. https://doi.org/10.30736/jes.v1i2.21 


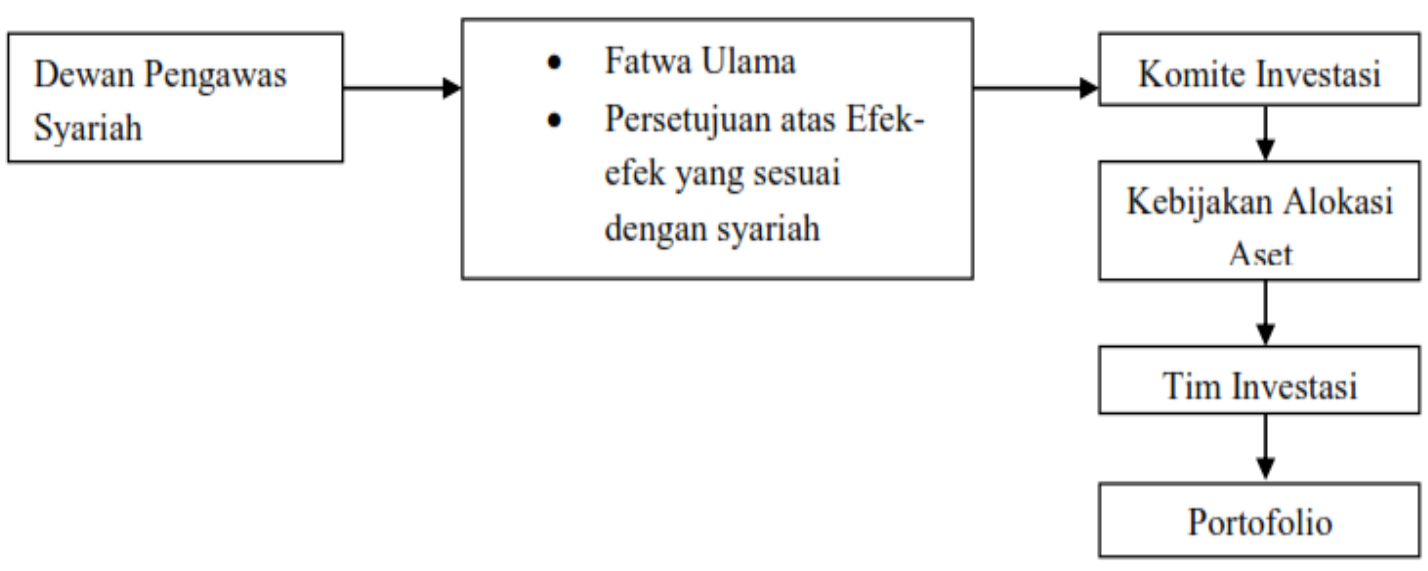

Gambar di atas menjelaskan proses pengelolahan reksadana syariah, pengawas syariah merupakan lembaga yang berwenang untuk mengkaji, menggali dan merumuskan nilai dan prinsip-prinsip hukum syariah dalam bentuk fatwa untuk dijadikan pedoman dalam kegiatan transaksi yang terjadi di lembaga keuangan syariah dan menyetujui efek-efek yang sesuai dengan prinsip syariah. ${ }^{10}$ Pedoman tersebut digunakan komite investasi untuk menyusun tujuan, kebijakan dan strategi investasi yang kemudian dilaksanakan oleh tim investasi dalam bentuk portofolio efek yang sesuai dengan prinsip-prinsip syariah.

\section{Kinerja Reksadana Syariah}

Ada dua hal penting yang harus di pertimbangkan dalam mengukur kinerja reksa dana syariah, yaitu: (a). Tingkat hasil (rate of return) yang diperoleh sama atau lebih besar dari tingkat hasil portofolio (return portofolio) tertentu dengan resiko yang sama atau lebih kecil dari tingkat resiko pasar (market risk). (b). Melakukan diversifikasi sehingga dapat

10 Soemitra Andri. 2010. Bank dan Lembaga Keuangan Syariah. Jakarta: Prenada Media Kencana. meminimalisirkan risiko yang tidak sistematis yang diukur dengan menghitung korelasi antara tingkat hasil reksa dana syariah dengan tingkat hasil portofolio pasar modal. ${ }^{11}$

Kinerja reksadana syariah tidak selalu menjamin kinerja yang baik, tetapi reksadana syariah menjamin kinerja sesuai dengan prinsip syariah dan halal. Kinerja reksadana syariah tergantung pada bagaimana peranan manajer investasi untuk mengoperasikan sistem kinerjanya dan menjaga kreditbilitas. Baik dan buruk kinerja reksadana tersebut dapat berpengaruh terhadap pertumbuhan nilai aktiva bersih (NAB), apabila kinerjanya baik maka nilai aktiva bersih akan naik sehingga meningkatkan nilai investasi terhadap pemegang unit penyertaan. Sedangkan kinerja investasi tersebut buruk maka nilai aktiva bersih akan turun sehingga menurunkan nilai investasi yang dimiliki oleh investor. Secara karakter instrumen investasi reksadana syariah

11 Zamzany, F. R., \& Setiawan, E. (2018). Studi Komparatif Kinerja Reksadana Saham Konvensional dan Syariah Di Indonesia. Akuntabilitas, 11(2). https://doi.org/10.15408/akt.v11i2.8794 
tidak jauh berbeda dengan reksadana konvensional.

\section{Keuntungan dan Risiko Investasi melalui Reksadana Syariah}

Hal utama yang membedakan antara reksadana syariah dengan reksadana jenis lainnya adalah penempatan dana atau investasinya. Reksadana syariah akan menempatkan dana ke dalam perusahaan yang bidang usahanya tidak bertentangan dengan prinsip syariah seperti bank kustodian. Investasi reksadana syariah memang sangat sesuai untuk jangka panjang, karena dapat meminimalkan volatilitas imbal hasil bagi investor. Pilihan reksadana pun semakin banyak, di antaranya reksadana IPB syariah, danareksa syariah berimbang, reksadana PNM ekuitas syariah, cipta syariah balance.

Menurut Sutedi (2011), keuntungan yang diperoleh pemodal atau investor jika berinvestasi melalui reksadana syariah antara lain: (a) Pemodal yang tidak memiliki dana cukup besar untuk berinvestasi, dapat melakukan diversifikasi investasi dalam efek sehingga dapat memperkecil risiko. Reksadana syariah bertujuan untuk dapat membantu instrument di pasar uang maupun pasar modal. (b) Mempermudah pemodal untuk melakukan investasi di pasar modal secara bebas. Pemodal dengan memeliki pemahaman yang baik mengenai investor, lebih mudah untuk menentukan saham-saham yang baik untuk dibeli. (c) Efesiensi waktu. Investor tidak perlu setiap saat memantau kinerja investasinya, karena hal tersebut telah dialihkan kepada manajer investasi. ${ }^{12}$

Seperti halnya produk investasi lainnya, di samping mendatangkan berbagai peluang keuntungan, reksadana syariah juga mengandung berbagai peluang resiko untuk investor yang berinvestasi dengan reksadana syariah antara lain: (a). Risiko Berkuranganya Nilai Unit Penyertaan, Risiko ini dipengaruhi oleh turunya harga dari efek (saham, obligasi, dan surat berharga lainnya) yang masuk dalam portofolio reksadana syariah. (2). Risiko Likuiditas, risiko ini menyangkut kesulitan yang dihadapi oleh manajer investasi jika sebagian besar pemegang unit melakukan penjualan kembali (redemption) atas unit-unit yang dipegangnya. Apabila hal tersebut terjadi, Manajer investasi kesulitan dalam menyediakan uang tunai atas redemtion tersebut. (3). Risiko Wanprestasi, risiko ini merupakan risiko yang terburuk, karena dapat menyebabkan penurunan nilai aktiva bersih (NAB).

Apabila investor ingin melakukan investasi melalui reksadana syariah, investor sebaiknya mengetahui keuntungan yang didapatkan dan risiko yang terjadi. Hal ini, tidak mengakibatkan pandangan negatif terhadap keinginan masyarakat untuk berinvestasi melalui reksadana syariah di pasar modal.

12 Sutedi Adrian. 2011. Pasar Modal Syariah Sarana Investasi Keuangan; Berdasarkan Prinsip-prinsip Syariah. Jakarta: Sinar Grafika. 


\section{Jenis Reksadana Syariah}

Reksadana syariah dirancang untuk menghimpun dana dari masyarakat (investor) yang mempunyai waktu, pengetahuan dan modal yang terbatas sehingga mampu meningkatkan peran modal lokal mereka. Adanya berbagai jenis reksadana syariah, investor bebas memilih jenis reksadana syariah yang dapat menguntungkan, karena setiap jenis reksadana syariah memiliki kelebihan dan kelemahan.

Menurut Sutedi (2011) jenis-jenis reksadana antara lain: (1) Reksadana pasar uang (money market funds), hanya melakukan investasi pada efek yang bersifat utang dengan jatuh tempo kurang dari 1 tahun. Tujuannya untuk menjaga likiuditas dan pemeliharaan modal investasi; (2) reksadana pendapatan tetap (fixed income funds), melakukan investasi sekurang-kurangnya $80 \%$ dari aktivanya dalam bentuk efek bersifat utang. Berinvestasi dengan reksadana pendapatan tetap ini memiliki resiko yang relatif besar dibandingkan dari reksadana pasar uang. Tujuan untuk menghasilkan tingkat pengembalian yang stabil; (3) reksadana saham (equity funds), melakukan investasi sekurang-kurangnya $80 \%$ dari aktivanya dalam bentuk efek bersifat ekuitas. Sifat investasi dari reksadana saham ini risikonya lebih tinggi dari dua jenis reksadana saham dan reksadana pendapatan tetap, namun menghasilkan tingkat pengembalian yang tinggi; (4) reksadana campuran (Mix Funds), reksadana jenis ini melakukan investasi dalam efek bersifat ekuitas dan efek bersifat utang. ${ }^{13}$

Investasi reksadana syariah tidak hanya bertujuan mendapatkan retrun yang tinggi dan tidak melakukan maksimalisasi kesejahteraan yang tinggi terhadap pemilik modal atau investor. Investasi reksadana syariah juga memperhatikan portofolio yang dimiliki investor tetap berada pada aspek investasi pada perusahaan yang memiliki produk halal dan baik yang tidak melanggar aturan syariah.

\section{Kendala Pengembangan Reksadana Syariah}

Perkembangan beberapa produk syariah di pasar modal Indonesia, khususnya reksadana syariah dalam beberapa tahun terakhir ini mengalami perkembangan yang cukup signifikan dan stabil. Namun, pengembangan reksadana syariah tersebut juga mengalami beberapa kendala dalam pengembangannya. Menurut Sudarsono (2004) kendala pengembangan reksadana syariah disebabkan oleh beberapa faktor, antara lain:

a. Reksadana relatif dikenal hanya pada kalangan tertentu terutama pada investor yang akan menanamkan modalnya dan masyarakat yang mempunyai kepentingan terhadap keberadaan reksadana syariah, sehingga reksadana syariah masih relatif kurang dikenal oleh masyarakat pada umumnya.

b. Adanya sistem dualisme dalam pasar modal yang menawarkan berinvestasi

13 Sutedi Adrian. 2011. Pasar Modal Syariah Sarana Investasi Keuangan; Berdasarkan Prinsip-prinsip Syariah. Jakarta: Sinar Grafika. 
melalui reksadana konvesional dan reksadana syariah. Reksadana konvensional memiliki peluang yang cukup besar karena masyarakat memilih reksadana yang berpengalaman di pasar modal, sedangkan untuk reksadana syariah belum cukup untuk membantu dalam aspek perekonomian, dikarenakan investasi di syariah kreditnya lebih tinggi dan return investasinya tidak terlalu besar. Berinvestasi di reksadana konvensional dan reksadana syariah pasti memiliki risiko.

c. Meningkatkan perkembangan dan pertumbuhan reksadana syariah perlu bantuan dari pengusaha dan lembagalembaga yang bersangkutan untuk sinergi bagi peningkatkan perkembangan reksadana di berbagai sektor ekonomi dan memperkenalkan ekonomi syariah di internasional. ${ }^{14}$

Kendala pengembangan reksadana syariah sebagian besar dipengaruhi oleh minimalnya pemahaman masyarakat tentang berinvestasi di syariah. Masyarakat beranggapan investasi melalui reksadana syariah masih diperuntukkan bagi umat muslim. Terlepas dari kendala tersebut perkembangan reksadana syariah sampai dengan tahun 2013 cukup stabil apabila dibandingkan dengan tahun sebelumnya. Peranan dari pemerintah, BAPEPAM, pengusaha, praktisi, akademisi dan ulama sangat berpengaruh dalam mendorong terbangunnya sistem bisnis syariah ter- utama di pasar modal untuk tetap menjaga eksistensi reksadana syariah di tahun berikutnya. Kendala ini juga disebabkan oleh adanya anggapan bahwa untuk melakukan investasi di pasar modal syariah dibutuhkan biaya yang relatif lebih mahal jika dibandingkan dengan investasi pada sektor keuangan lain dan memiliki risiko yang tinggi.

\section{SIMPULAN}

Semakin berkembangnya reksadana syariah di Indonesia saat ini dapat memenuhi kebutuhan investor yang ingin berinvestasi secara syariat Islam. Perkembangan reksadana syariah ini juga memiliki prospek yang menjanjikan untuk sektor ekonomi dimasa yang akan datang apabila sistem kinerjanya berjalan dengan baik dan pemerintah menyediakan suatu aturan yang lebih memadai mengenai investasi syariah di pasar modal.

Faktor yang dapat menghambat perkembangan reksadana syariah disebabkan oleh masyarakat umum masih belum mengenal adanya reksadana syariah. Masyarakat masih beranggapan bahwa berinvestasi melalui reksadana syariah hanya diperuntukkan bagi umat muslim dan masyarakat lebih memilih berinvestasi ke konvensional karena reksadana konvensional lebih berpengalaman. Berinvestasi di reksadana syariah relatif lebih mahal dan keuntungan yang didapatkan investor lebih rendah. 



\section{DAFTAR PUSTAKA}

Rodoni, A. (2008). Lembaga Keuangan, Jakarta Timur: Zikrul Hakim.

Waridah, W., \& Mediawati, E. (2016). Analisis Kinerja Reksadana Syariah. Jurnal Riset Akuntansi Dan Keuangan, Vol.4. No.(2). https://doi.org/10.17509/jrak.v4i2.4043

Hamzah, A., \& Yohanes, A. (2014). Analisis Perbandingan Kinerja Reksadana Syariah dengan Rekadana Konvensional Jenis Saham. Jurnal MIX Vol.IV No.3.

Ridha, M.R., Nasution, B., \& Siregar, M. (2013). Peranan Reksadana Syariah dalam Peningkatan Investasi di Indonesia. Jurnal Hukum Ekonomi Vol 02. No.02.

Cahyono J. E. (2000), Cara Jitu Memilih Untung dari Reksadana, Jakarta: Elex Media Komputindo.

Sari, R. P. (2018). Perbandingan Reksadana Syariah Dengan Reksadana Konvensional Dalam Dunia Perbankan. Al-Intaj : Jurnal Ekonomi Dan Perbankan Syariah, Vol. 4 No.(1). ttps://doi.org/10.29300/aij.v4i1.1203

Ghofur, A.A. (2008). Aspek Hukum Reksa Dana Syariah di Indonesia.

Zakariya, M. (2017). Pertumbuhan Lembaga Reksadana Syariah Di Indonesia. JES (Jurnal Ekonomi Syariah), Vol.1. No.(2),https://doi.org/10.30736/jes.v1i2.21

Soemitra, A. (2010). Bank dan Lembaga Keuangan Syariah. Jakarta: Prenada Media Kencana.

Zamzany, F. R., \& Setiawan, E. (2018). Studi Komparatif Kinerja Reksadana Saham Konvensional dan Syariah Di Indonesia. Akuntabilitas, Vol. 11 No. (2). https://doi.org/10.15408/akt.v11i2.8794

Sutedi, A. (2011). Pasar Modal Syariah Sarana Investasi Keuangan; Berdasarkan Prinsipprinsip Syariah. Jakarta: Sinar Grafika.

Sumar'in, S. (2017). Memahami Reksadana Syariah: Instrumen Keuangan Berbasis Syariah. Al-Amwal: Journal of Islamic Economic Law, Vol. 2. No.(2),. https://doi.org/10.24256/alw.v2i2.637 
